\title{
Study on seam performance of polymer-modified bituminous roofing membranes using T-peel test and microscopy
}

\author{
Koichi Oba1, Sivotha Hean ${ }^{1}$, Folke Björk ${ }^{2}$ \\ (1) Swiss Federal Laboratories for Materials Testing and Research, CH-8600 Dïbendorf, Switzerland. \\ (2) Division of Building Technology/BIM, Royal Institute of Technology, S-100 44 Stockholm, Sweden.
}

\section{A B S T R A C T}

The aim of the study was to understand how the Tpeel strength of heat-welded seams in polymer-modified bituminous roofing membranes depends on the welding method and on the material properties.

Seam samples of ten different commercial products, three of Atactic Polypropylene (APP)-modified bitumen and seven of Styrene-Butadiene-Styrene copolymer (SBS)modified bitumen, were prepared by different welding methods with different heating media, i.e. hot air or gas torch, welding speed and weight of pressure roller joining seams. The welding conditions were precisely controlled during the preparation, and the temperature in the seam sample was measured.

T-peel tests were carried out at $23^{\circ} \mathrm{C}$ and at $-10^{\circ} \mathrm{C}$ on specimens cut out from each heat-welded sample to measure the T-peel strengths. The fracture propagation during T-peel testing was studied visually. Some seam specimens were also studied using microscopy.

In order to identify the material properties and differences in the material compositions influencing the seam strengths, each product was characterised by different chemical and thermal methods, which were described in recently published reports $[1,2]$.

It was concluded that the choice of welding speed and pressure weight for the optimum design of welding machine should make reference to the thermal properties, such as specific heat, and to the rheological properties, such as viscosity.

\section{INTRODUCTION}

During the mid-'70s, a change in the roofing industry in the developed countries took place with the introduction of single-ply roofing systems using thermoset rubbers and thermoplastics. During the $80 \mathrm{~s}$, a polymer-modified bituminous roofing membrane was introduced for singleply roofing systems. Unlike the conventional built-up roofing (BUR)-system, this single-ply roofing system creates a lightweight structure, since the waterproofing layer

\section{R É S U M É}

Le but de cette étude était de déterminer l'influence exercée par la méthode de soudage et les caractéristiques du matériau sur la résistance an "T-peel test" des joints soudés à chaud des lés d'étanchéité de bitume polymère $(L B P)$ pour toitures.

Des éprouvettes de joints soudés de dix produits commerciaux, trois à base de bitume modifié par du polypropplène atactique (APP) et sept à base de bitume modifié par un copolymère styrènebutadiène-styrène (SBS), ont été confectioniées avec différentes méthodes de soudage witilisant des agents de chauffage divers, air chaud ou torche à gaz, ainsi que des.vitesses et des pressions de soudage différentes. Durant la confection des éprouvettes, on a contrôlé avec précision les conditions de soudage et on a procédé à la mesure de la température des éprouvettes.

Les "T-peel tests" ont été effectués à $23^{\circ} \mathrm{C}$ er à $-10^{\circ} \mathrm{C}$ sur des éprouvettes de chacun des joints soudés afin de mesurer leur résistance au "T-peel test ". La propagation des fissures a été examinée visuellement. Sur certaines éprouvettes de joints soudés on a également procédé à un examen microscopique.

Afin de déterminer les caractéristiques et les différences de composition du matériau exerçant une influence sur la résistance des joints soudés, chaque produit a été caractérisé au moyen de différentes méthodes d'analyse chimique et thermique qui sont décrites dans les rapports [1, 2] précédemment publiés.

Les conclusions de cette étude sont que le choix de la vitesse de soudage et de la force de pression pour le réglage optimal de la machine de soudage devraient s'effectuer en fonction des caractéristiques thermiques, telles que la chaleur spécifique, et de caracéristiques rhéologiques, telles que la viscosité des lés d'étanchéité de bitume polymère.

is a thin, single layer. A membrane is often mechanically fastened to the roof structure along one of the long edges, and then seamed with the next membrane overlapping the fastened edge of the previous one [3]. Compared to the conventional BUR-system, the system is advantageous as it reduces labour and materials costs [4]. The system, called the mechanically-fastened single-ply roofing system, has been used in Sweden for renovations of old roofs as well as for new buildings. In some countries, polymer-modified bituminous roofing membranes are used in two or more-ply 
systems. The market share of conventional asphalt rooting felts seems to have been taken over by, above all, polvmermodified bituminous roofing membranes.

To ensure a satisfactory single-ply waterproofing system using polymer-modified bituminous roofing felts, good joints in the overlaps are necessary [5]. Field studies have shown that unsatisfactory adhesion in seams is the most common problem causing leakage [6-8]. The seams are often made using open gas torching, though this may create a fire hazard. The surfaces to be joined or attached to the underlay are heated with a flame at more than $1000^{\circ} \mathrm{C}$, and the joint will have good adhesion when it hardens after cooling. The flame of the open gas torch soon provides enough energy to melt the substrate surfaces, so that the welding can be carried out in a minimum of time [9]. The shorter the time for the welding work, the ligher the cost effectiveness. In contrast, however, the fire hazard increases through the use of an open gas torch at such high temperatures. Fires caused by the use of open gas torching during roof installation work have led to enormous damage costs [10, 11], and between 1985 and 1990, such costs reached 249 million Swedish crowns. The Swedish Fire Protection Association together with the Roofing Contractors' Association reached an agreement about the education and certification of roofers. Meanwhile the insurance companies have started to demand welding methods with lower temperatures and a reduced fire hazard [9].

For this reason, it became necessary to use alternative welding methods instead of the conventional open gastorch method. Two main types of alternative welding methods were recently introduced: one using a gun distributing electrically-heated hot air at about $60^{\circ} \mathrm{C}$, and another using a gas burner distributing an enclosed gas flame at about $800^{\circ} \mathrm{C}$ to limit the uncontrolled spread of gas during welding. The earlier study has shown that both methods have reduced the fire hazard by lowering the welding temperature [12].

When polymer-modified bituminous roof coverings are to be welded, it is important that the adherends at the overlap seams are heated to a temperature high enough to ensure that the macromolecules or chain segments at the interface will acquire sufficient mobility for interdiffusion across the interface [13]. In an earlier study [14], it was concluded that for the bituminous roofing materials, there were minimum hot air temperatures that should be exceeded to form seams of acceptable T-peel strength. In practice, the welding temperature is adjusted to a maximum and the welding speed varied to allow for climatic conditions. On the other hand, the higher the welding temperature used for joining, the greater the fire hazard. and the risk of thermal deterioration in the roofing membranes will also increase. When faster welding speeds are used, the installation costs are reduced, but the material will have less opportunity to achieve good bonds, and the more quickly welded seams will have less strength. Fig.1 illustrates these counteracting parameters for the optinization of both the installation work and seam performance [12].

The purpose of the study is to understand how the Tpeel strength of heat-welded seams in polymer-modified bituminous roofing membranes was influenced by different welding parameters and differences in material compositions, e.g. polymer, bitumen types and impregnation of reinforcement.

This paper describes the preparation of seam samples of ten different polymer-modified bitumen products with different welding methods as well as the evaluation of seam strengths of the seam samples using T-peel testing and microscopy.

\section{MATERIALS}

Ten different commercial single-ply roofing products, normally seamed by heat welding, were chosen for this study: seven products of Styrene-Butadiene-Styrene copolymer (SBS)-modified bitumen and three products of Atactic Polypropylene (APP)-modified bitumen. The specifications of these products are listed in Table 1.

\section{EXPERIMENTS}

\subsection{Material characterization}

\subsubsection{Penetration test and ring and ball softening point test}

A bituminous material is often characterized using mechanical tests such as the penetration test and the ring and ball $(R \& B)$ softening point test. In this study, the penetration test using Penetrometer and R\&B softening point test using Ring and Ball MC 753 were carried out according to Swiss standards SN 671 740a and SN $671743 a$, respectively.

\subsubsection{Dynamic viscosity measurement}

To study the rheological behaviour of a tested sample over a temperature range for heat-weldings, dynamic viscosity measurements were carried out using a drag rheometer Rheomat 115, which is composed of a coaxial cylindrical bob with conical ends rotating in a cup containing the materials being tested. The temperature of the sample was controlled by $\mathrm{Cr} 400$ according to a temperature program. When the measuring bob inserted in the sample rotates at constant shear rate, a load cell connected to the bob measures the shear stress caused by the pull of the sample. The viscosity (in Pascal seconds, $\mathrm{Pa} . \mathrm{s})$ was then calculated by dividing the shear stress measured in Pascals by the shear rate (per second, s-1). Both the Rheomat 115 and the $\mathrm{Cr} 400$ were comnected to a Rheoscan 100 which enabled measurements at different shear rates during a temperature program.

The sample was carefully taken from the reverse side of a roofing membrane to avoid other substances such as reinforcements and glass fibre felts. For SBS-products, after the membrane was conditioned at $-10^{\circ} \mathrm{C}$ for about 5 min. the polyethylene films on the reverse side were removed by compressed air. For APP-products, the sand-coated surfaces on the reverse side were removed by peeling off an 


\begin{tabular}{|c|c|c|c|c|}
\hline \multicolumn{5}{|c|}{ Table 1 - List of tested products } \\
\hline Product & $\begin{array}{l}\text { Bltumen } \\
\text { (Type) }\end{array}$ & Polymer & $\begin{array}{l}\text { Filler } \\
\text { Amount }\end{array}$ & Reinforcement \\
\hline Product-1 & $\begin{array}{l}\text { Bitumen-1 } \\
\text { (Pen 180) }\end{array}$ & $\begin{array}{l}\text { SBS-1 ( } 70 / 30 \text { blend } \\
\text { of radial and linear types) } \\
\left(M_{w} 2.98\right)\end{array}$ & $30 \%$ & Non-woven polyester $220 \mathrm{~g} / \mathrm{m}^{2}+$ aluminium foil \\
\hline Product-2 & $\begin{array}{l}\text { Bitumen-1 } \\
\text { (Pen 180) }\end{array}$ & $\begin{array}{l}\text { SBS-2 }(100 \% \text { radial }) \\
\left(M_{w} 3.69\right)\end{array}$ & $30 \%$ & Non-woven polyester $220 \mathrm{~g} / \mathrm{m}^{2}+$ aluminium foil \\
\hline Product-3 & $\begin{array}{l}\text { Bitumen-1 } \\
\text { (Pen 180) }\end{array}$ & $\begin{array}{l}\text { SBS-3 }(100 \% \text { radial }) \\
\left(M_{w} 3.47\right)\end{array}$ & $30 \%$ & Non-woven polyester $220 \mathrm{~g} / \mathrm{m}^{2}+$ aluminium foil \\
\hline Product-4 & $\begin{array}{l}\text { Bitumen-2 } \\
\text { (Pen 200) }\end{array}$ & $\begin{array}{l}\text { SBS-4 }(100 \% \text { radial }) \\
\left(M_{w} 4.03\right)\end{array}$ & $40 \%$ & Non-woven polyester $210 \mathrm{~g} / \mathrm{m}^{2}+$ aluminium foil $40 \mathrm{~g} / \mathrm{m}^{2}$ \\
\hline Product-5 & $\begin{array}{l}\text { Bitumen-3 } \\
\text { (Pen 140) + } \\
\text { Bitumen-4 } \\
(30 / 100)\end{array}$ & $\begin{array}{l}\text { SBS-5 }(100 \% \text { radial }) \\
\left(M_{w} 1.52\right)\end{array}$ & $35 \%$ & Non-woven polyester $180 \mathrm{~g} / \mathrm{m}^{2}$ \\
\hline Product-6 & $\begin{array}{l}\text { Bitumen-5 } \\
\text { (Pen 200) }\end{array}$ & $\begin{array}{l}\text { SBS-6 }(100 \% \text { radial }) \\
\left(M_{w} 3.73\right)\end{array}$ & $35 \%$ & Non-woven polyester $180 \mathrm{~g} / \mathrm{m}^{2}$ \\
\hline Product-7 & $\begin{array}{l}\text { Bitumen-6 } \\
\text { (Pen 220) }\end{array}$ & $\begin{array}{l}\text { SBS-6 }(100 \% \text { radial }) \\
\left(M_{w} 3.73\right)\end{array}$ & $40 \%$ & Non-woven polyester $210 \mathrm{~g} / \mathrm{m}^{2}+$ aluminium foil $40 \mathrm{~g} / \mathrm{m}^{2}$ \\
\hline Product-8 & $\begin{array}{l}\text { Bitumen-7 } \\
\text { (Pen 100) }\end{array}$ & $\begin{array}{l}\text { APP-1* } \\
\text { (Crystallinity } 1.65 \%)\end{array}$ & $10 \%$ & Fiberglass mat $50 \mathrm{~g} / \mathrm{m}^{2}+$ Non-woven Polyester $160 \mathrm{~g} / \mathrm{m}^{2}$ \\
\hline Product-9 & $\begin{array}{l}\text { Bitumen-7 } \\
\text { (Pen 100) }\end{array}$ & $\begin{array}{l}\text { APP-2* } \\
\text { (Crystallinity } 1.21 \% \text { ) }\end{array}$ & $30 \%$ & Fiberglass mat $50 \mathrm{~g} / \mathrm{m}^{2}+$ Non-woven polyester $130 \mathrm{~g} / \mathrm{m}^{2}$ \\
\hline Product-10 & $\begin{array}{l}\text { Bitumen-7 } \\
\text { (Pen 100) }\end{array}$ & $\begin{array}{l}\text { APP-3* } \\
\text { (Crystallinity } 1.20 \%)\end{array}$ & $17 \%$ & Fiberglass mat $50 \mathrm{~g} / \mathrm{m}^{2}+$ Non-woven polyester $160 \mathrm{~g} / \mathrm{m}^{2}$ \\
\hline
\end{tabular}

* not able to be obtained

Bitumen-4 is oxidized bitumen

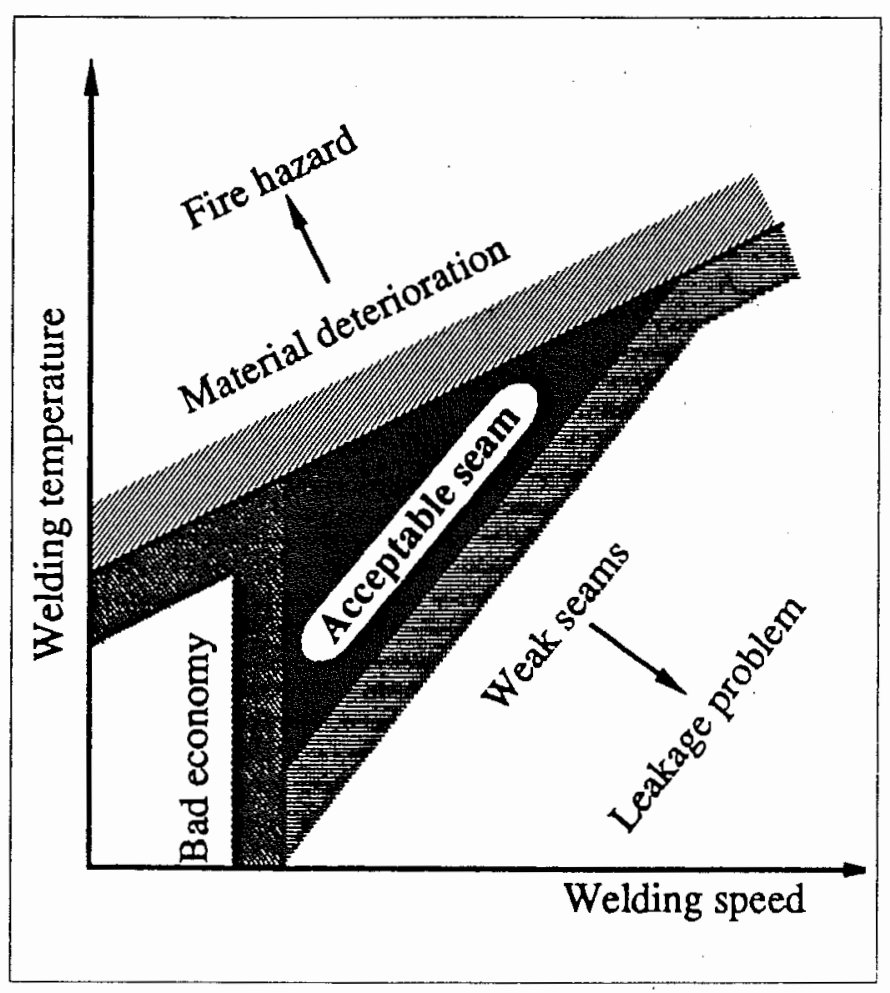

Fig. 1 - Parameters influencing the weldings of polymermodified bituminous roofing membranes. aluminium foil attached to the reverse side by epoxy glue. The sample was then melted into an aluminium cup held in an oven connected to the temperature controller. The viscosity was measured at six different temperatures, namely $100^{\circ}, 120^{\circ}, 140^{\circ}, 160^{\circ}, 180^{\circ}$ and $200^{\circ} \mathrm{C}$. At each temperature, the rotation speed was increased up to a certain shear rate for four minutes; thereafter, the shear stress of the sample was measured for 1 minute at a constant shear rate. Rotation was then reduced to zero within 4 minutes. It took $j$ minutes to reach each temperature step, and the sample was kept at that temperature for $25 \mathrm{~min}$. The repeatability of the test was previously checked by double testing the sample Product 8 . The maximun variation was $5 \%$, and was less at higher temperatures.

\subsubsection{Study of dispersity polymer/bitumen blend using microscopy}

To understand how a homogeneous polymer/ bitumen blend acts when it is subjected to a very high temperature during heat welding, dispersity of the blend during heating was studied using a Wild M8 Stereo microscope with a Wild MPS 55 Photoautomat. A sample of about $1 \mathrm{~mm}^{3}$ was taken from the reverse side of the roofing membrane and carefully pressed on the microscope slide to obtain a thin layer through which light could pass. The slide was placed in a heating panel, Mikroskop Heiztisch Leitz 350, which was connected to a manually-controlled heating 
regulator. To control the heating rate at about $1^{\circ} \mathrm{C} / \mathrm{min}$, a thermocouple was inserted in the heating panel. The sample was first heated from $30^{\circ}$ to $80^{\circ} \mathrm{C}$ at about $5^{\circ} \mathrm{C} / \mathrm{min}$, then heated to $200^{\circ} \mathrm{C}$ at about $1^{\circ} \mathrm{C} / \mathrm{min}$. At each temperature, $100^{\circ}, 120^{\circ}, 140^{\circ}, 160^{\circ}, 180^{\circ}$ and $200^{\circ} \mathrm{C}$, the sample was kept at a constant temperature for $1 \mathrm{~min}$ to enable a photograph to be taken.

\subsection{Study of seam strengths and structures}

\subsubsection{Preparation of seam samples}

For the preparation of seam samples, a hot air gun and a pressure roller were mounted on the horizontal driving unit of a lathe, so that the welding speed and the weight of the pressure roller could be easily changed. Weldings were carried out at room temperature, $23^{\circ} \mathrm{C}$. Several seam samples of different qualities were prepared by changing different parameters, e.g. heating medium (hot air or gas), pressure roller weight $(3.0,7.2$ or $13.2 \mathrm{~kg})$, and welding speed ( 1 or $2 \mathrm{~m} / \mathrm{min}$ ). Both the air flow rate and the temperature of hot air were kept constant for all weldings. The welding speed was also kept constant during each welding. The temperatures of the hot air in the nozzle and also inside the welded seam were measured by using type K (Chromel/Alumel) thermocouples. Temperature variations over time were recorded on a pen writer.

For weldings, two adherends of each roofing product, $600 \mathrm{~mm}$ long and $500 \mathrm{~mm}$ wide, were laid on a 10-nm thick gypsum board as an underlay base placed on the 300-mm thick polystyrene insulation material. The hot air distribution nozzle (opening width $75 \mathrm{~mm}$ ) of the gun mounted on the machine was placed at the corner of the adherends, to weld along the long edges of the adherends. A pressure roller (width $110 \mathrm{~mm}$ ) placed $50 \mathrm{~mm}$ from the nozzle opening pressed the heated seam surfaces together immediately after heating, see Fig.2. All welded seam samples were conditioned in a climate chamber at $20^{\circ} \mathrm{C}, 50 \% \mathrm{RH}$ for a week. Six test specimens measuring $50 \times 150 \mathrm{~mm}$ were then cut out of each sample, for the measurement of seam strengths by $T$-peel test.

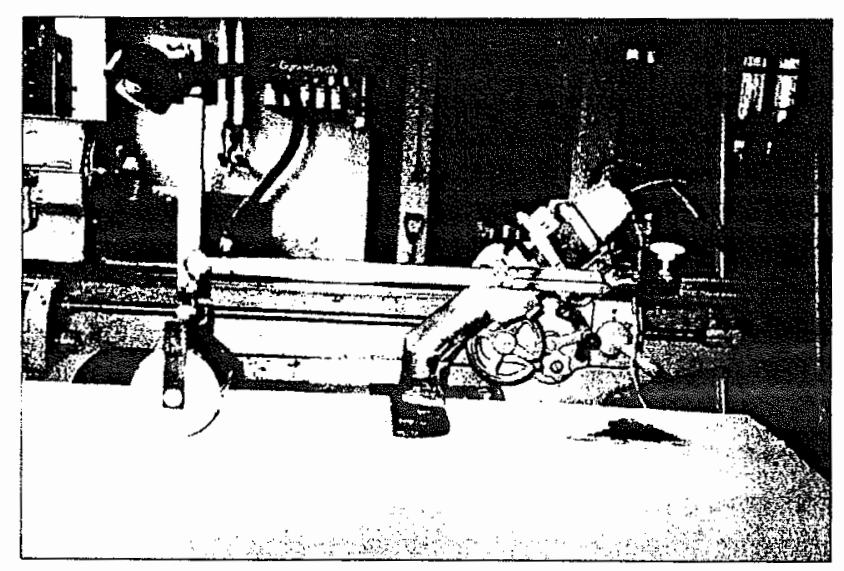

Fig. 2 - Modified welding apparatus for the sample preparation.

\subsubsection{T-peel test}

The T-peel test is one of the methods for measuring the mechanical strength of a seam specimen by applying a peel force under a constant extension rate. The T-peel test was carried out using an EMPA UVP-Testing machine. In this machine, the two ends of a specimen were clamped in the grips and stretched at a constant extension rate of $100 \mathrm{~mm} / \mathrm{min}$ (Fig.3). The mechanical load applied to peel the seam specimen is then measured using a load cell. Six specimens could be tested simultaneously with individual load cells. From the data registered on the pen writer during the tests, it was possible to calculate the maxinum T-peel strength, i.e. maximum T-peel load divided by specimen width (N/mm).

The $\mathrm{T}$-peel rest was done in triplicate for each product at both $23^{\circ} \mathrm{C}$ and $-10^{\circ} \mathrm{C}$ in accordance with a testing proposal, CEN/TC $117 \mathrm{~N}$. The T-peel specimens for $-10^{\circ} \mathrm{C}$ were conditioned in the cooling box regulated at $-10^{\circ} \mathrm{C}$ for 12 hours before the tests in order to stabilize the material temperature.

\subsubsection{Study on fracture mode}

The pattern of fractured surfaces of the tested specimens is a useful tool for examining qualitatively the fracture propagation during a T-peel test. Earlier studies [3,14] showed a correlation between fracture modes revealed during the T-peel test and the T-peel strengths. Two types of fracture modes were observed for polymer-modified bituminous products as shown in Fig. 3 : a cohesive fracture, i.e. a fracture propagated along the embedded reinforcement in one of the adherends (Type A), and an interfacial fracture, i.e. a fracture propagated along the boundary surface between the adherends (Type B).

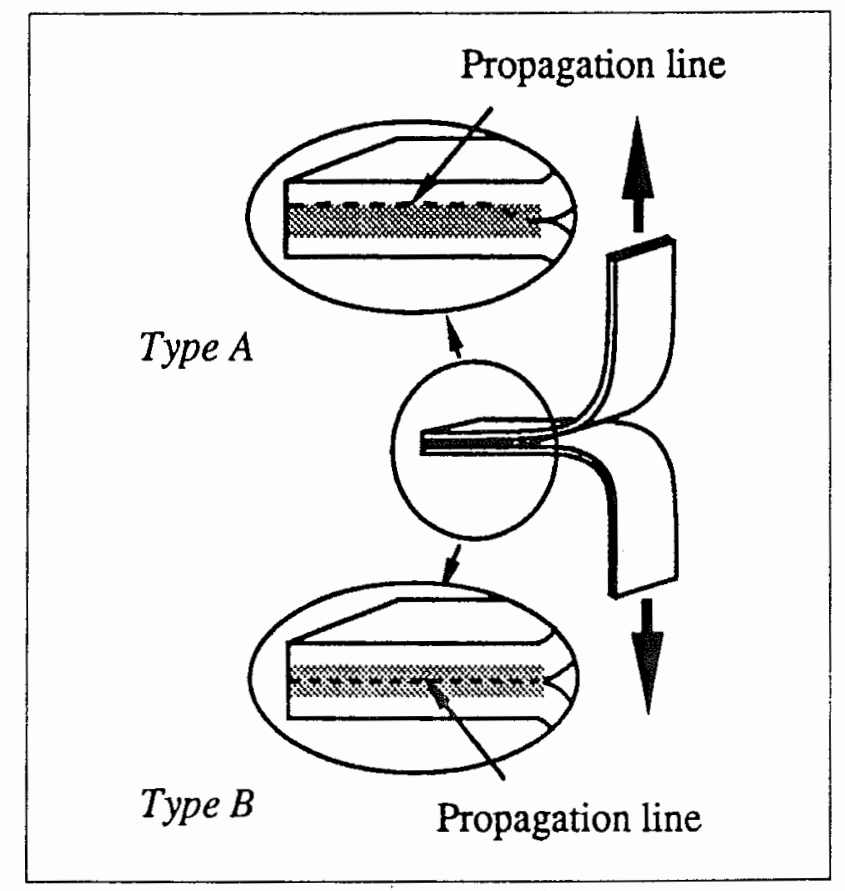

Fig. 3 - Fracture modes revealed by T-peel test. 


\subsubsection{Microscopy}

Weak adhesion is often caused by poor interfacial contact due to air voids or uncleaned surfaces between adherends [15]. Observation of the interfacial area in the seam specimens was made using light microscopy and fluorescence microscopy.

\subsubsection{Light microscopy}

The structures of polymer-modified bituminous roofing membranes and the dispersity of polymer/ bitumen blend can be studied under a microscope by preparing a thin sliced sample [16]. The instrument used was a Wild M8 Stereo microscope with a Wild MPS 55 Photoautomat. The seam samples were sliced into sections $20 \mu \mathrm{m}$ thick using an E.Leitz Wetzler microtome so that the sample can transmit the light from below. Before slicing, the T-peel specimens were conditioned at $-10^{\circ} \mathrm{C}$ for about $30 \mathrm{~min}$. The sample holder was kept at $-20^{\circ} \mathrm{C}$ during slicing.

\subsubsection{Fluorescence microscopy}

Fluorescence is an emitted electromagnetic radiation caused by the flow of some form of energy into the emitting body and it ceases abruptly when the excitation ceases. When the subject is illuminated by ultraviolet light, violet, and sometimes blue radiation, the specimen will fluoresce. Fluorescence microscopy has been used for the study of the homogeneity and dispersity of the polymer/bitumen blend after aging $[17,19]$.

The flat surfaces of the T-peel specimens sectionally sliced using the microtome as described earlier were studied using a Fluorescence microscopy Zeiss Axioskop. The microscope was connected to a Winder M476079-9901 M35 and photo regulator Zeiss MC 63.

\section{RESULTS AND DISCUSSIONS}

\subsection{Material characterization}

\subsubsection{Penetration test and $R \& B$ softening point test}

The R\&B softening points for APP-products (155$156^{\circ} \mathrm{C}$ ) were more than $30^{\circ} \mathrm{C}$ higher than for SBSproducts $\left(111-125^{\circ} \mathrm{C}\right)$, which is in good agreement with the results obtained by Diebold [20]. It means that APPproducts generally have a higher temperature range application than do SBS-products. For Product-5 (SBSproduct containing oxidized bitumen), the penetration and the $R \& B$ softening point were the lowest of all (penetration $25 \mathrm{dmm}, \mathrm{R} \& \mathrm{~B} 111^{\circ} \mathrm{C}$ ). The difference in penetration for different products was small $(25-52 \mathrm{dmm})$. No significant correlation in penetration and R\&B softening point temperature was observed for Products-1, 2 and 3, although these products are composed of the same bitumen with different SBS-polymers. Nor was any influence by the compositions observed for the APPproducts. According to Heimerikx, the $\mathrm{R} \& \mathrm{~B}$ softening point temperature is influenced by the molecular weight of the SBS-polymer in a SBS/bitumen blend [21].

\subsubsection{Dynamic viscosity measurement}

The results for Products-1 (SBS-product), 5 (SBSproduct containing oxidized bitumen) and 8 (APPproduct) are compared in Fig.4. The curves of Products-1 and 8 intersect at about $140^{\circ} \mathrm{C}$, which is in good agreement with the results shown by Diebold [20]. At temperatures higher than $140^{\circ} \mathrm{C}$, the APP-product has lower viscosity than the SBS-product, which indicates that it flows more easily at high temperatures. This means that at high

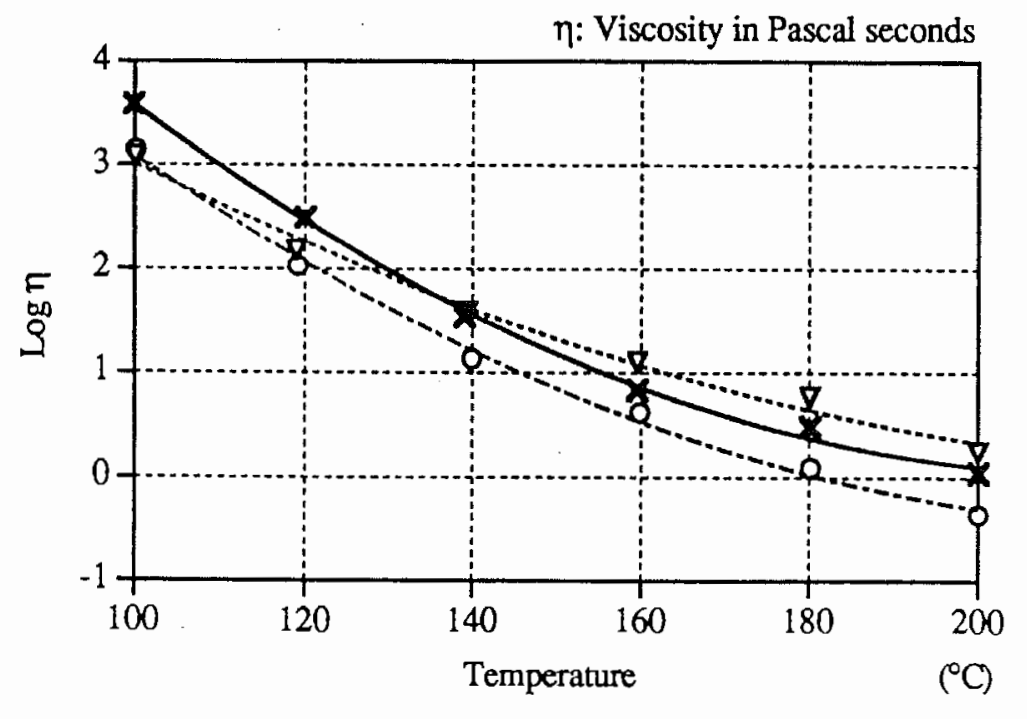

$x$ Product-8 (APP-modified bitumen) $y=0.0003 x^{2}-0.1 x-10 r^{2}=1$

$\nabla$ Product-1 (SBS-modified bitumen) $\gamma=0.0001 x^{2}-0.007 \times 8 r^{2}=1$

o Product-5 (SBS-modified bitumen containing oxidized bitumen)

$y=0.00\left(2 x^{2}-0.01 x-10 r^{2}=1\right.$

Fig. 4 - Comparison of viscosities of APP-and SBS-products as a function of temperature. 
temperatures, the APP-product is more sensitive to the pressure weight during welding than is the SBS-product. Product -5 had the lowest viscosity of all the products.

Comparison of Products-1-3, composed of different types of SBS-polvmers with the same original bitumen binder, has shown that Products-2 and 3, made of a radial type of SBS-polymer, i.e. with higher molecular weights, had higher viscosities than Product-1, containing 30\%
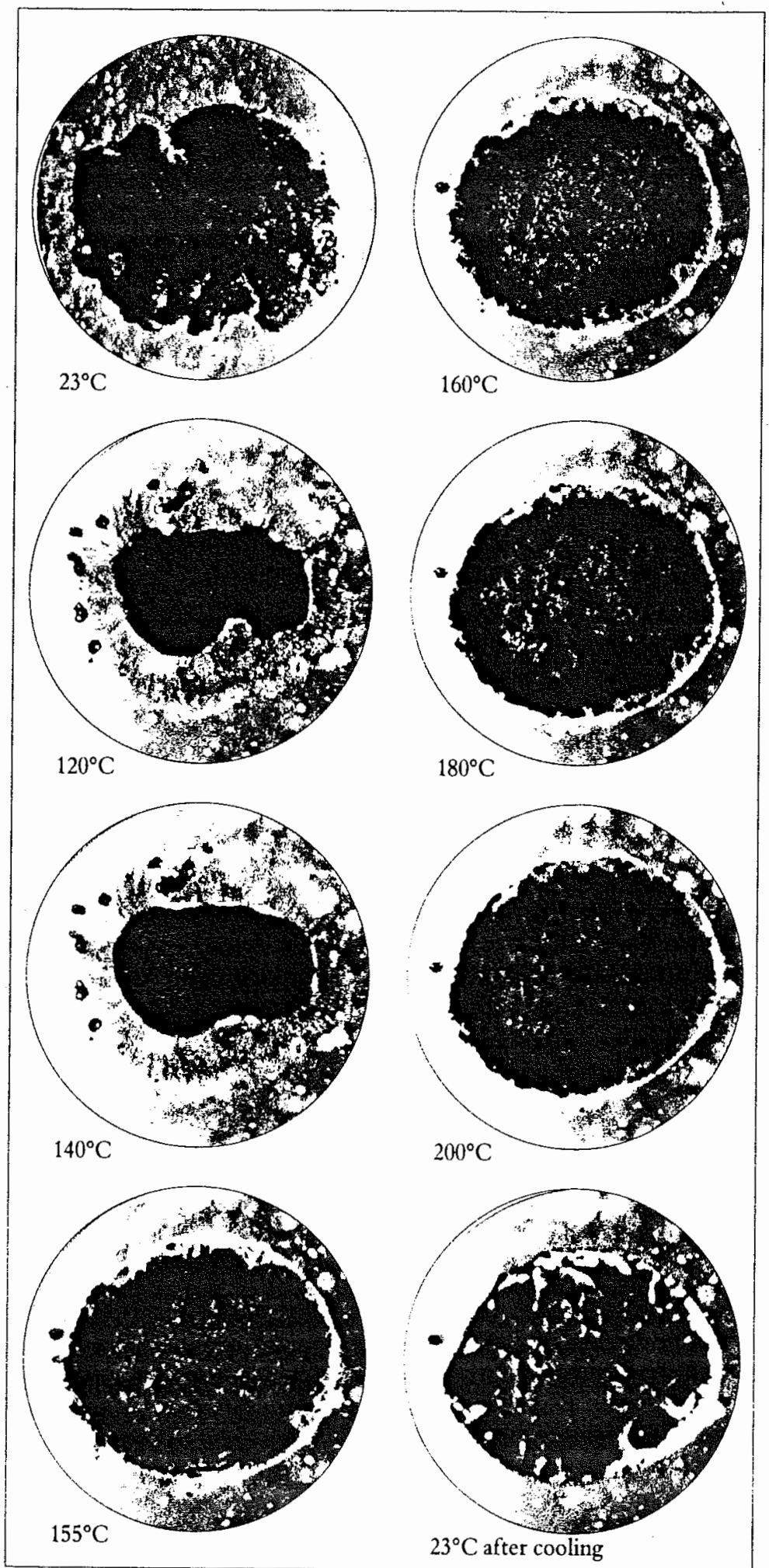

Fig. 5 - Study of dispersity of APP/bitumen blend (Product 10) at different temperatures using microscopy, approx. $x 17.5$ linear type of SBS-polymer. According to Heinerikx [21], viscosity at $180^{\circ} \mathrm{C}$ increases along with the increasing molecular weight of the SBS-polymer. For Products-4, 6 and 7 , the products are not directly comparable, since they are made of different bitumen binders. The viscosity of Product- 4 was lower than those of Product- 6 and Product-7. For different APP-products, Products-8, 9 and 10, the difference in viscosity was small, even though the differences in filler contents were quite large (10-30\%).

\subsubsection{Study of dispersity polymer/bitumen blend using microscopy}

The results of studving dispersity of the APPpolymer/bitumen blend (Product-10) by microscope during heating are shown in Fig. 5. As the temperature increased, the sample started to contract up to $120^{\circ} \mathrm{C}$ and then to swell at about $140^{\circ} \mathrm{C}$. At these temperatures, the sample became a thicker film which cannot transmit light. At $155^{\circ} \mathrm{C}$, the bitumen (black spots) finely dispersed in the APP-polymer (orange in color photo) could be observed. No filler particles could be clearly identified. At temperatures over $160^{\circ} \mathrm{C}$. the bitumen dispersion became coarse and the accumulating bitumen dispersions formed clusters. The clusters of bitumen grew as the temperature was increased. It suggests that phase separation of APPpolymer/bitumen blend may occur by heating to temperatures over $160^{\circ} \mathrm{C}$ at $1^{\circ} \mathrm{C} / \mathrm{min}$ heating speed. However, additional investigation is necessary to associate this result with the degradation in the bulk of polymermodified bitumen during weldings in practice. The sample cooled down to $23^{\circ} \mathrm{C}$ after heating at $200^{\circ} \mathrm{C}$ is also shown.

For SBS-modified bitumen, dispersion of the polymer/ bitumen blend could be observed from about $120^{\circ} \mathrm{C}$. However, the observation was not as clear as for APPmodified bitumen, because the dispersion of the SBSpolymer/bitumen blend looked more smooth.

\subsection{Study of seam strengths and structures}

\subsubsection{T-peel test}

The results of T-peel tests at $23^{\circ} \mathrm{C}$ are sumnnarized in Table 2. Comparison of the SBS-products, Products-1-3 (composed of same original bitumen with different types of SBS-polymer), showed that the T-peel strengths were nearly independent of the type of SBS-polymer. The Tpeel strengths of Product $\mathbf{5}$, containing oxidized binmen, were approximately $2.0 \mathrm{~N} / \mathrm{mm}$, about $1 / 3$ of those for other SBS-products. The values were similar to the T-peel strengths of conventional asphalt roofing felts [3].

At a $1 \mathrm{~m} / \mathrm{min}$ welding speed, for SBS-products $1-3$ and 4-7, T-peel strengths were constant at about $6.0 \mathrm{~N} / \mathrm{mm}$ independent of pressure roller weight. At a speed of $2 \mathrm{~m} / \mathrm{min}$, T-peel strengths increased with a greater weight of pressure roller. This is in good agreement with the earlier study [12], which concluded that the T-peel strength was dependent on the welding speeds. The T-peel strengths of the specimens prepared using gas were not as high as for specimens made using hot air. 


\begin{tabular}{|c|c|c|c|c|c|c|c|c|}
\hline \multirow{3}{*}{$\begin{array}{l}\text { Speed } \\
\text { W. }\end{array}$} & \multicolumn{6}{|c|}{ Hot air } & \multirow{2}{*}{\multicolumn{2}{|c|}{$\underset{1 \mathrm{~m} / \mathrm{min} \mid 2 \mathrm{~m} / \mathrm{min}}{\cos }$}} \\
\hline & & $1 \mathrm{~m} / \mathrm{min}$ & & & $2 \mathrm{~m} / \mathrm{min}$ & & & \\
\hline & $3.0 \mathrm{~kg}$ & $7.2 \mathrm{~kg}$ & $13.2 \mathrm{~kg}$ & $3.0 \mathrm{~kg}$ & $7.2 \mathrm{~kg}$ & $\mid 13.2 \mathrm{~kg}$ & $7.2 \mathrm{~kg}$ & $7.2 \mathrm{~kg}$ \\
\hline Product-1 & 6.7 & 6.7 & 6.7 & 4.7 & 5.6 & 6.9 & 5.3 & 6.5 \\
\hline Product-2 & 6.8 & 7.0 & 6.9 & 4.8 & 5.8 & 6.5 & 5.8 & 6.5 \\
\hline Product-3 & 7.0 & 6.8 & 7.1 & 6.0 & 5.5 & 6.2 & 5.7 & 5.6 \\
\hline Product-4 & 5.9 & 6.7 & 6.2 & 5.1 & 6.9 & 6.2 & 4.9 & 4.6 \\
\hline Product-5 & 1.8 & 2.1 & 1.8 & 1.7 & 1.9 & 2.4 & 1.5 & 1.9 \\
\hline Product-6 & 6.1 & 6.6 & 6.9 & 3.5 & 3.0 & 5.0 & 5.3 & 5.2 \\
\hline Product-7 & 5.4 & 5.8 & 5.7 & 3.1 & 4.3 & 3.9 & 4.7 & 4.2 \\
\hline Product-8 & 1.7 & 1.7 & 1.2 & 1.1 & 1.4 & 1.3 & 1.0 & 1.1 \\
\hline Product-9 & 1.5 & 0.9 & 1.3 & 1.2 & 1.2 & 1.5 & 1.3 & 1.5 \\
\hline Product-10 & 1.4 & 1.3 & 1.9 & 1.4 & 1.5 & 1.8 & 1.4 & 1.5 \\
\hline
\end{tabular}

A comparison of the APP-products-8-10 (composed of the same original bitumen modified with APP-polymer of different crystallinity) showed no significant difference. The tendency of T-peel strengths to increase slightly as pressure roller weight increases is also noted with respect to the $2 \mathrm{~m} / \mathrm{min}$ welding speed. No difference in T-peel strengths between the weldings with hot air and gas is observed. The T-peel strengths of APP-products are about $1 / 3$ of those for SBS-products, which is in good agreement with the earlier studies $[3,12,14]$. However, this does not necessarily mean that APP-modified bitumen has a seam performance inferior to that of SBS-modified bitumen, since the T-peel strength required for satisfactory seam performance differs for different products, and depends on the design of the roofing system.

The results of T-peel tests at $-10^{\circ} \mathrm{C}$ are summarized in Table 3. For SBS-products-1-3, T-peel strengths are more than twice as high as those at $23^{\circ} \mathrm{C}$. On the other hand, for SBS-products-4-7. T-peel strengths decreased slightly compared with those at $23^{\circ} \mathrm{C}$. The temperature at which SBS-modified bitumen becomes brittle is approximately $-60^{\circ} \mathrm{C}$, according to Fraass (approx. $-20^{\circ} \mathrm{C}$ for APPmodified bitumen) [20]. For non-modified bitumen, this temperature is between $-20^{\circ}$ and $0^{\circ} \mathrm{C}$ depending on the grade of bitumen. In the study of fracture modes revealed by T-peel testing, for Products-4-7 only the cohesive type of fracture (Type A: Fracture propagated along the embedded reinforcement in one of the adherends) was observed, while for Products-1-3 the types of fracture mode varied. The investigation using Fluorescence Microscopy showed that for Products-1-3 the reinforcement was innpregiated with polymer-modified bitumen (see Fig.10), while for Products-4-7 it was impregnated with non-modified bitumen (see Fig.11) [22]. It can be concluded that the decrease in T-peel strengths for Products- $-4-7$ at $-10{ }^{\circ} \mathrm{C}$ was caused by brittleness along the reinforcement inpregnated with non-modified bitumen. No influence of welding methods on T-peel strengths was observed at $-10^{\circ} \mathrm{C}$.

An increase in $\mathrm{T}$-peel strengths at $-10^{\circ} \mathrm{C}$ was also
Table 3 - Results of T-peel strengths $[\mathrm{N} / \mathrm{mm}]$ using T-peel test at $-10^{\circ} \mathrm{C}$

\begin{tabular}{|c|c|c|c|c|c|c|c|c|}
\hline & \multicolumn{5}{|c|}{ Hot air } & \multicolumn{2}{c|}{ Gas } \\
\hline $\begin{array}{c}\text { Speed } \\
\text { Wt. }\end{array}$ & \multicolumn{3}{|c|}{$1 \mathrm{~m} / \mathrm{min}$} & \multicolumn{3}{c|}{$2 \mathrm{~m} / \mathrm{min}$} & $1 \mathrm{~m} / \mathrm{min} / 2 \mathrm{~m} / \mathrm{min} \mid$ \\
\hline Product-1 & 14.9 & - & 12.7 & 9.0 & - & 13.4 & 12.7 & 14.9 \\
\hline Product-2 & 14.8 & 15.5 & 14.4 & 12.1 & 13.8 & 13.7 & 15.0 & 15.9 \\
\hline Product-3 & 12.1 & 12.9 & 14.6 & 12.1 & 13.4 & 12.2 & 7.9 & 12.2 \\
\hline Product-4 & 3.3 & 2.7 & 2.5 & 3.5 & 3.2 & 3.5 & 2.9 & 3.2 \\
\hline Product-5 & 1.2 & 1.2 & 1.0 & 1.2 & 1.0 & 1.5 & 1.5 & 0.8 \\
\hline Product-6 & 5.2 & 4.8 & 4.7 & 4.4 & 4.1 & 4.9 & 5.0 & 4.2 \\
\hline Product-7 & 4.1 & 4.2 & 4.3 & 4.2 & 4.3 & 4.4 & 4.0 & 4.2 \\
\hline Product-8 & 3.4 & 2.8 & 3.9 & 2.9 & 4.0 & 3.1 & 4.0 & 3.3 \\
\hline Product-9 & 3.8 & 3.9 & 4.6 & 3.2 & 3.6 & 3.3 & 3.3 & 4.0 \\
\hline Product-10 & 4.2 & 5.1 & 4.6 & 3.4 & 3.3 & 4.0 & 4.3 & 4.9 \\
\hline
\end{tabular}

recognized for APP-products-8-10. In the study using Fluorescence Microscopy, it was found that these products had the reinforcement impregnated with polymermodified bitumen [22]. No influence of welding methods on T-peel strengths was observed.

\subsubsection{Study of fracture modes revealed by T-peel testing}

When hot air is used for weldings, the fracture mode for SBS-products-1-3 by T-peel test at $23^{\circ} \mathrm{C}$ varied according to the welding speed and pressure roller weight. With gas welding, the fracture mode was mainly of type A (see Fig. 3). For SBS-products-4, 6 and 7, the specimens mainly showed fracture type $B$ regardless of welding speed and pressure roller weight. For APP-products-8-10, the fracture mode tends to vary according to the $T$-peel strength, i.e. fracture type $A$ is more frequent in specimens with higher T-peel strengths $[3,14]$.

The results of T-peel testing at $-10^{\circ} \mathrm{C}$ showed that for SBS-products- 1 and 3 the fracture mode varied, i.e. fracture mode type $A$ was more frequent at $1 \mathrm{~m} / \mathrm{min}$ than at $2 \mathrm{~m} / \mathrm{min}$. For Product-2, the specimens prepared using hot air showed only a type B fracture. For Products-4, 6 and 7 , all samples showed Type A fracture mode independent of welding speed and pressure roller weight, and this may be due to impregnation of the reinforcements by bitumen that is not polymer-modified.

For APP-products- 8 and 9, the main fracture mode observed was Type A. For Product-10, fracture mode type $B$ was more frequent at $2 \mathrm{~m} / \mathrm{min}$.

\subsubsection{Light microscopy}

Fig. 6 shows an area of heat-welded T-peel specimen studied using a microscope. A section of a T-peel specimen for Product-1 photographed using a light microscope is shown in Fig. 7. The fillers are recognized as white dotted particles of less than $1.0 \mathrm{~mm}$ diameter. At approx. $1.3 \mathrm{~mm}$ from the bottom, a thin aluminium foil is observed as a 
black line (D). Just above this, a membrane of non-woven polyester about $0.8 \mathrm{~mm}$ thick lies as a carrier (C). At $4 \mathrm{~mm}$ from the bottom (the same as the thickness of the roofing membrane), an unjoined seam boundary can be clearly observed as a white line (B). A possible reason for this void is that the adherends were not properly pressed together during the welding as the sample was taken from the edge of the seam specimen. In general, it was difficult to identify the seam boundary region for SBS-product using lightscattered microscopy.

In Fig. 8, a section of a T-peel specimen for Product-7 is shown. Along the polyester reinforcement, a black band of non-modified bitumen was observed (C). Compared to the specimen shown in Fig. 7, relatively many holes were recognized in the reinforcement. These were probably formed during preparation of the sample because slicing of the sample for microscopy was possible when it was kept at $-20^{\circ} \mathrm{C}$, a temperature at which the non-modified bitumen became brittle. The same phenomenon was observed for Product-4 and 6 [22]. The sample preparation from a seam specimen of Product-5 containing oxidized bitumen was unsuccessful because the whole specimen became brittle at $-20^{\circ} \mathrm{C}$. For oxidized bituminous roofing membranes, the microscopic study is therefore not possible.

A section of the T-peel specimen for Product- 8 is shown in Fig. 9. The fracture was propagated along the embedded reinforcement. Non-woven polyester is observed at 0.7-1.4mm from the upper surface (B). The seam boundary is clearly identified by the change in darkness (D), possibly because the modified bitumen under the reinforcement is observed in darker colour than the modified bitumen above the reinforcement. In the layer between $C$ and D, relatively bigger droplets of bitumen dispersed in the polymer phase are observed. This means that the quality of the APP-polymer/bitumen blend in the layer between $C$ and $D$ may differ from that in the layer between $\mathrm{B}$ and $\mathrm{C}$. The bigger droplets observed in the blend between $\mathrm{C}$ and $\mathrm{D}$ may be due to the production process of the membrane, indicating the tendency of phase separation. The seam boundary was also able to be observed for Product-10 by the change in colour [22]. The bitumen droplets were relatively bigger in Product- 8 than in Product-10. For all products, the fillers are recognized as white dotted particles. In Product-9, fillers of somewhat bigger size were observed [22].

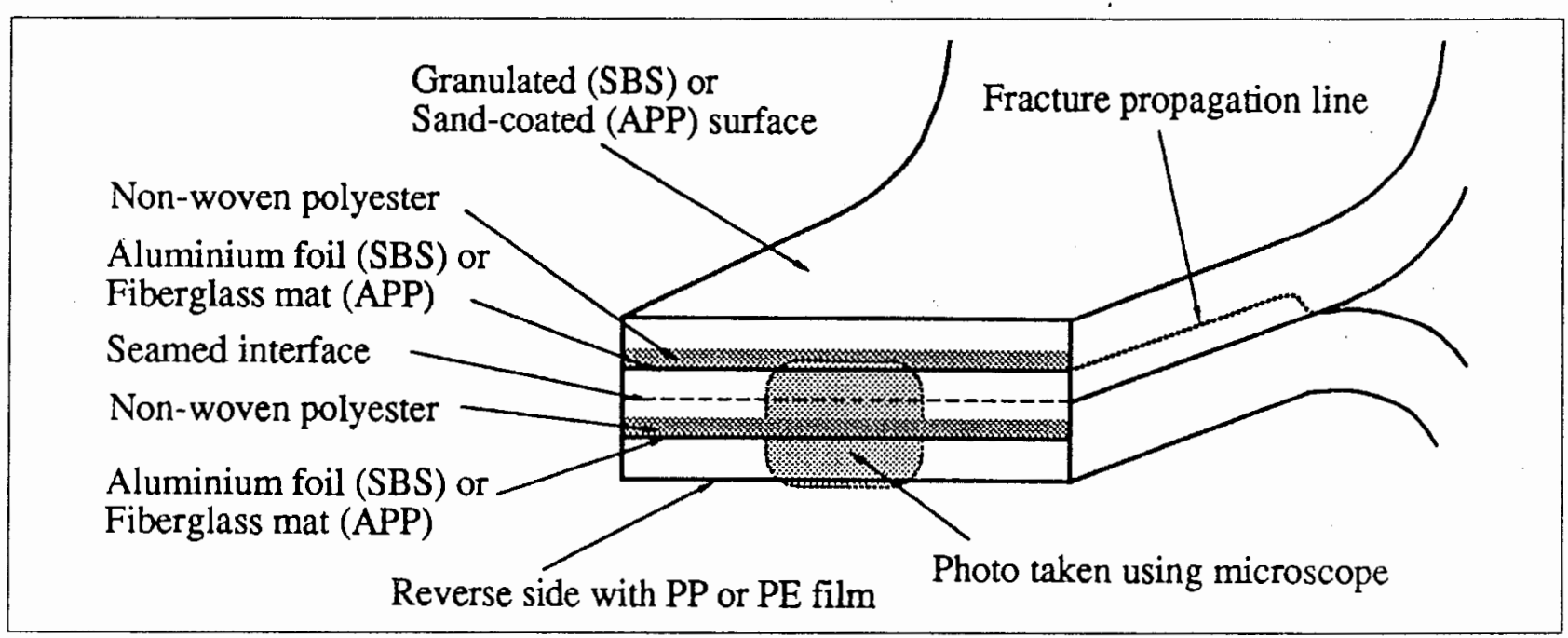

Fig. 6-Area of T-peel specimen studied using microscopy.
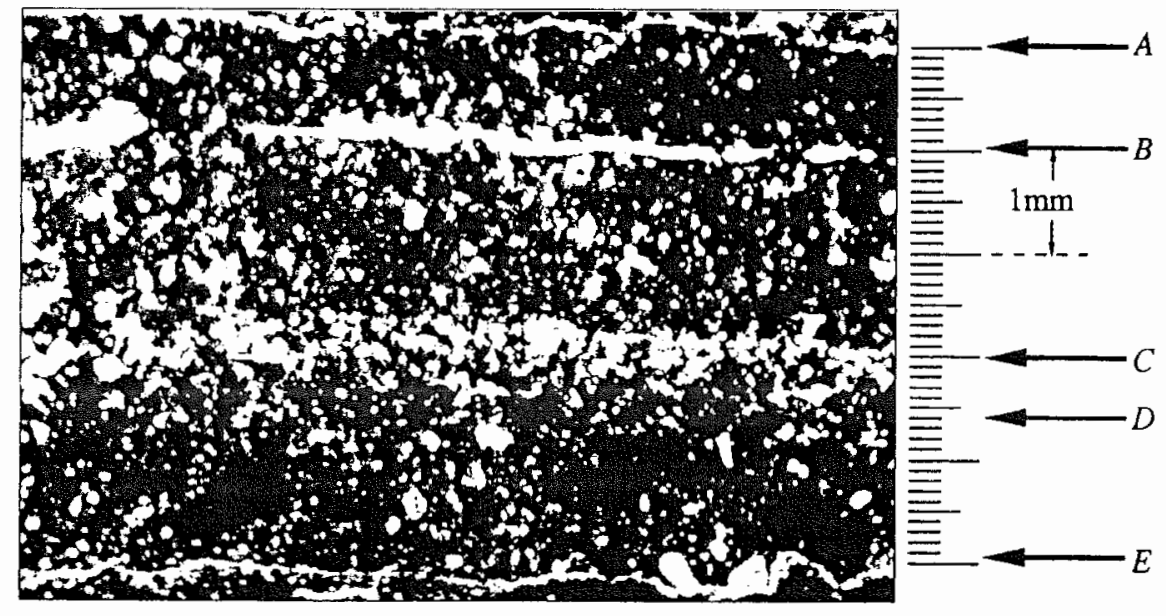

Fig. 7 - A section of $T$-peel specimen for SBS-product 1, approx. x 13.

A : Fracture propagation line

B : Seamed interface

$\mathrm{C}:$ Non-woven polyester

D: Aluminium foil

E: Underside of the membrane 


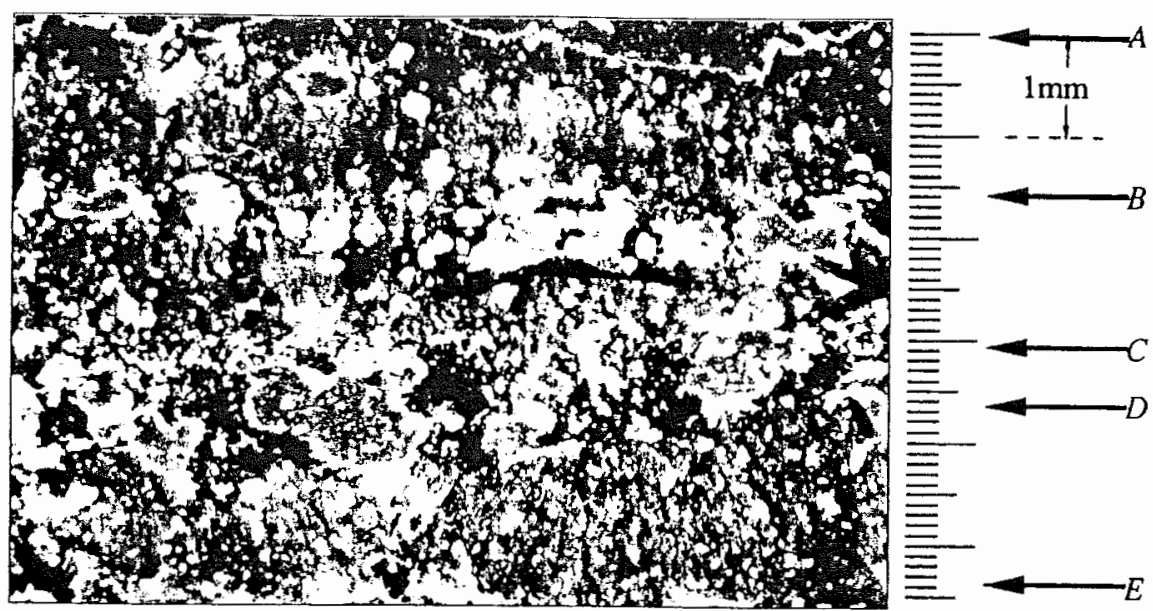

Fig. 8 - A section of T-peel specimen for SBS-product 7, approx. x 13.

A : Fracture propagation line

$B$ : Seamed interface

C: Non-woven polyester

$\mathrm{D}$ : Aluminium foil

$\mathrm{E}$ : Underside of the membrane
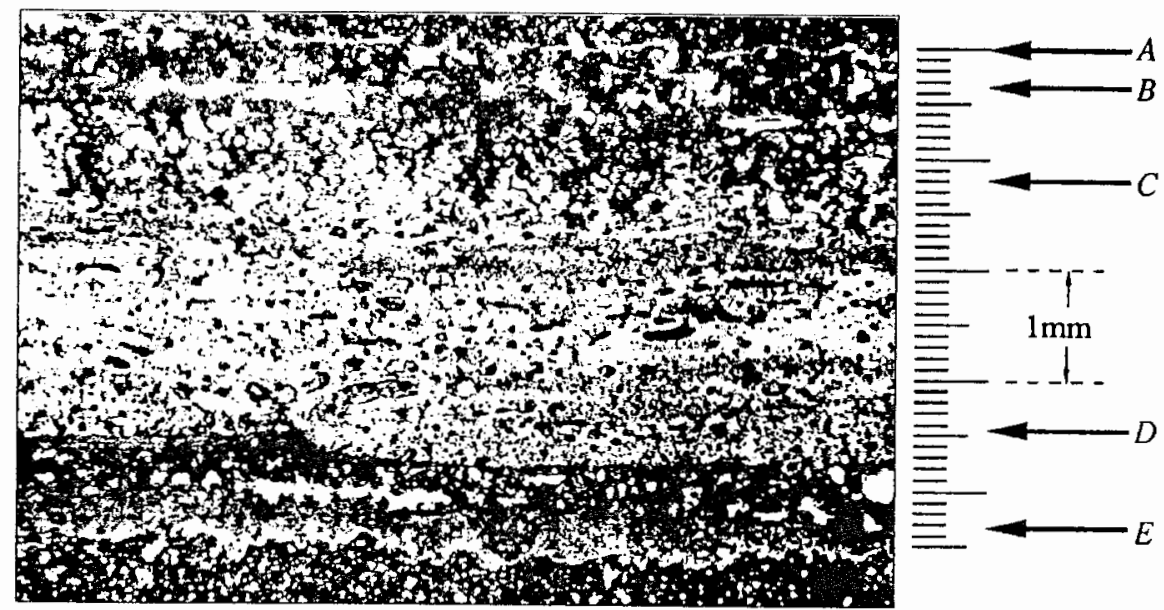

Fig. 9 - A section of T-peel specimen

for APP-product 8, approx. x 14

A: Upper surface

$B:$ Non-woven polyester

C: Fiberglass mat

$D$ : Seamed interface

E: Fracture propagation line

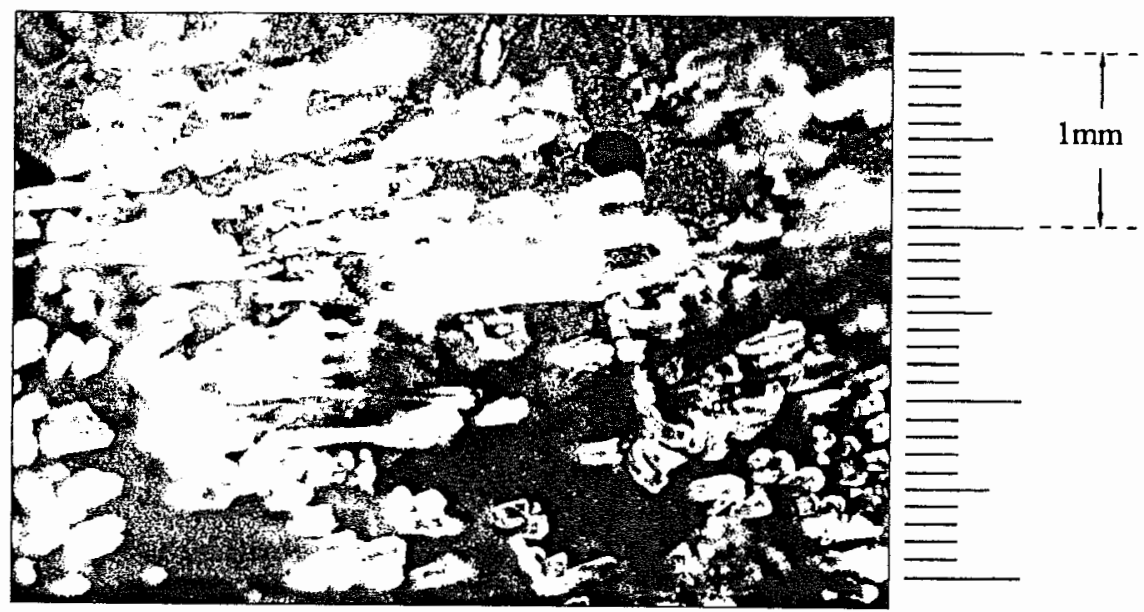

Fig. 10 - Impregnation of reinforcement for SBS-product 2. approx. x 22 .

\subsubsection{Fluorescence microscopy}

From the investigation using fluorescence microscopy, ic was found that for Products-1-3 the reinforcement was impregnated with polyner-modified bitumen, while for Products $-4-7$ it was impregnated with non-modified bitumen. Examples are shovin in Fig. 10 (Product-2) and 11 (Product-6). Non-woven polyester fibers in Product-2 (Fig. 10) are impregnated with polymer-modified bitumen (fluorescing yellow in color photo). Polyester fibers in Product-6 (Fig. 11) are, however, impregnated with non- modified bitumen which does not emit any fluorescence, and was therefore observed as black. The state of the impregnation could also be studied for APP-modified bitumen [22].

In Fig. 12, the seamed interface area for the APPmodified bitumen sample Product-10 is shown. The seam boundary $(A)$ is just visible in the middle. In the upper adherend, more and larger bitumen dispersion (black colored) is observed. The seam interface area could also be identified for SBS-modified bitumen [22]. 


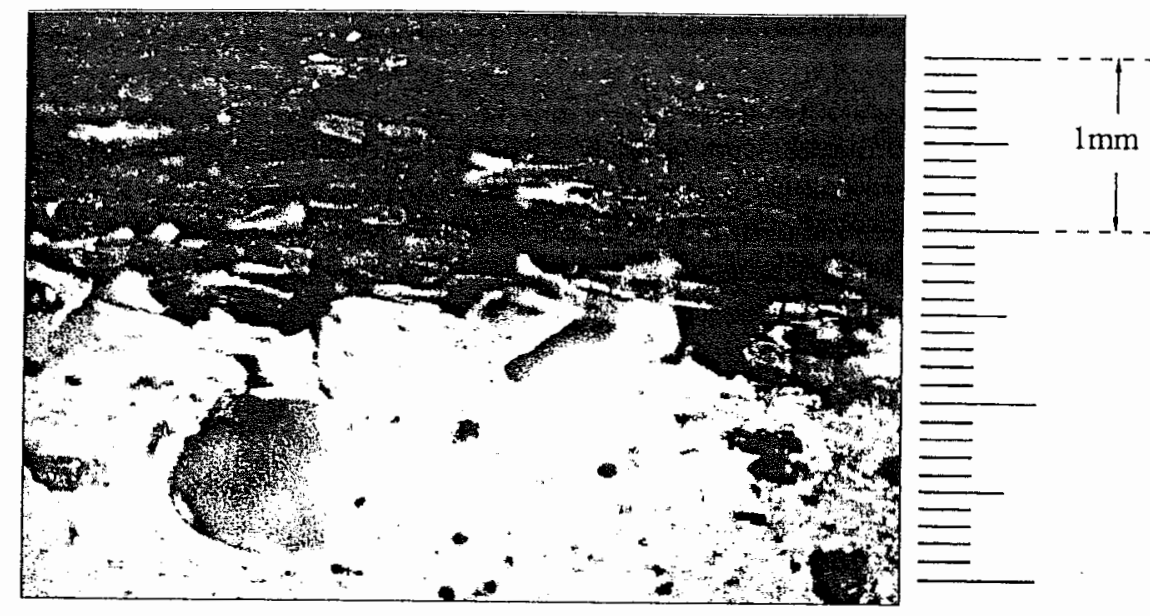

Fig. 11 - Impregnation of reinforcement for SBS-product 6 . approx. x 22

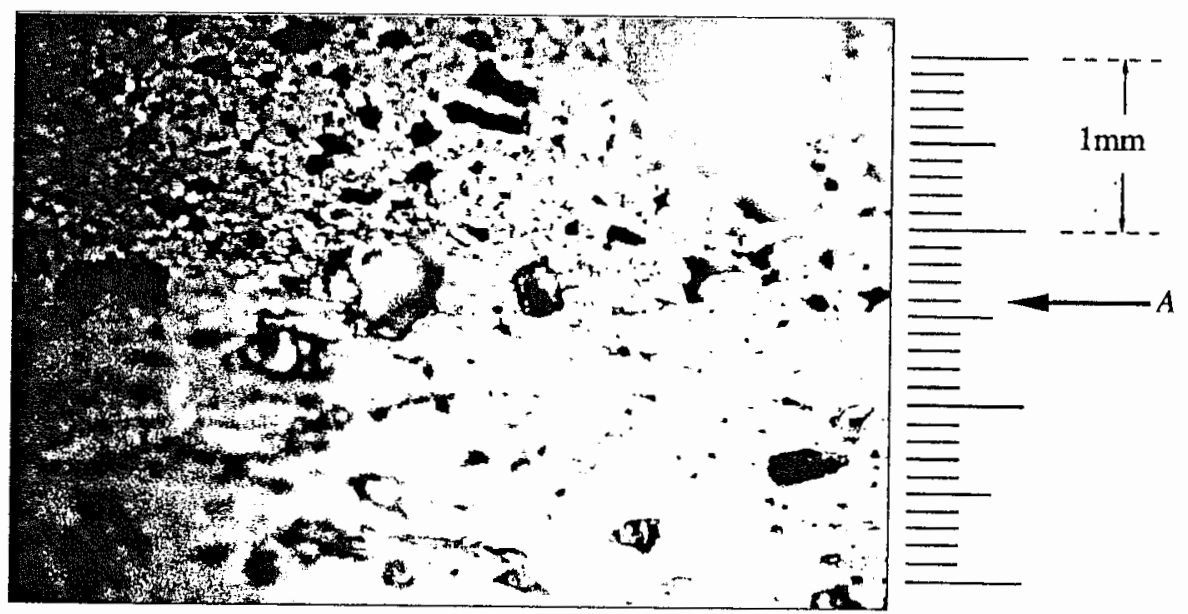

Fig. 12 - Seamed interface area for APP-product 10, approx. x 22 .

\section{CONCLUSIONS}

\subsection{Influence of material compositions and properties on T-peel strengths}

- The difference in dynamic viscosity between commercial SBS- or APP-modified bitumen products and different polymer types is not great. However, the difference in viscosity appears between APP-products, SBS-products and SBS-products containing oxidized bitumen, which may be due to the difference in asphaltene content. The bitumen type seems to affect the dynanic viscosity more than the type of polymer does. Where the results of heat welding are concerned, products with low viscosity at high temperatures may be more sensitive to the weight of the pressure roller during welding.

- The T-peel strengths of the products whose reinforcenents are impregnated with polymer-modified bitumen become more than twice as high at $-10^{\circ} \mathrm{C}$ as those at $23^{\circ} \mathrm{C}$. On the other hand, the T-peel strengths of the products whose reinforcements are impregnated with nonmodified bitumen decrease slightly at $-10^{\circ} \mathrm{C}$ compared with those at $23^{\circ} \mathrm{C}$. In the latter, the fracture propagates along the reinforcement layer by T-peel test at $-10^{\circ} \mathrm{C}$.

- Thus, the T-peel strengths of tested products measured using $\mathrm{T}$-peel test are in the following order:

- at $23^{\circ} \mathrm{C}$ : SBS-modified bitumen
- SBS-modified bitumen containing oxidized bitumen - APP-modified bitumen

- at $-10^{\circ} \mathrm{C}$ : SBS-modified bitumen (impregnated with polymer-modified bitumen)

- SBS-modified bitumen (impregnated with non-modified bitumen)

- SBS-modified bitumen containing oxidized bitumen - APP-modified bitumen.

\subsection{Influence of welding parameters on T-peel strengths}

- With hot air weldings, T-peel strengths measured at $23^{\circ} \mathrm{C}$ may be high throughout at a $1 \mathrm{~m} / \mathrm{min}$ welding speed independent of pressure roller weight. At $2 \mathrm{~m} / \mathrm{min}$, the Tpeel strengths may be more dependent on the weight of the pressure roller, i.e. higher at $13.2 \mathrm{~kg}$ than at $3 \mathrm{~kg}$. However, the welding method resulting in maxinum $\mathrm{T}$ peel strengths varies from product to product.

- When $1 \mathrm{~m} / \mathrm{min}$ welding speed is used, the T-peel strengths measured at $23^{\circ} \mathrm{C}$ are higher with hor air welding than with gas welding.

- In general, the difference in T-peel strengths between hot air and gas weldings is not great. The choice of welding method, hot air or gas welding, will therefore be constrained by fire safety requirements. 


\subsection{Additional conclusions}

The types of SBS-polymer do not show any significant influence on the penetration and $R \& B$ softening point temperatures of the products. The characterization of polymer-modified bitumen needs, therefore, to be supplemented by other methods, such as thermal analysis and chromatography described in the other reports $[1,2,22]$.

E The penetration and $\mathrm{R} \& \mathrm{~B}$ softening point temperatures of commercial products are influenced by the nature of bitumen (and probably the proportion of polymer/bitumen blend, which has not been studied herein), e.g. asphaltene content, rather than the type of SBS.

- By the study of dispersity of the polymer/bitumen blend, the tendency of phase separation of APPpolymer/bitumen blend could be observed at temperatures over $160^{\circ} \mathrm{C}$. However, additional investigation is necessary to associate this result with the degradation in the bulk of polymer-modified bitumen during weldings in practice. For SBS-polymer/bitumen blend, the observation was more difficult. Further investigation is necessary to state a definite conclusion on the phase separation of APPmodified bituminous roofing membrane heated to such temperatures during weldings.

- Light microscopy is a useful method for studying the structure of the polymer-modified bituninous roofing membrane. The location of material components, such as reinforcement and filler, the dispersity of the polymer/bitumen blend and the state of the impregnation can be studied. The method may be widely used for the quality assurance of roofing products before the application. For the product containing oxidized bitumen, this study was not possible because the sample was difficult to prepare.

- By light microscopy, the seam interlayer for APPmodified bitumen could be easily observed by the change in colour, while for SBS-modified bitumen it was generally difficult. The coarse bitumen dispersion observed for APP-products may be the indication of the phase separation of the APP-polymer/bitumen blend.

- By fluorescence microscopy, the impregnation of the roofing membrane can be studied. The seam interlayers could also be observed for both APP- and SBS-modified bituminous roofing nembranes. However, for the study of seam strengths using fluorescence microscopy, further investigation is necessary.

\section{ACKNOWLEDGEMENT}

Financial support by the Swedish Building Contractors Development Fund (SBUF Project No.2115) and Swiss Federal Laboratories for Materials Testing and Researcl (EMPA Project FE 147'135) as well as their permission for the publication of the results are gratefully acknowledged. Many thanks are also due to Dr. M. N. Partl at EMPA, Switzerland for his critical reviews.

\section{REFERENCES}

[1] Oba, K. and Hugener, M., 'Characterization of polymermoditied bituninous rooting membranes using chronarography Watcrials and Structures. 28, (1995), 534-544.

[2] Oba, K. and Roller. A.. 'Characterization of polymer-modified bituminous roofing membranes using thermal analysis', Materials and Structures, 28, (1995), 596-603.

[3] Oba, K. and Björk. F.. The influence of water on the mechanical strength of seams in single-ply coverings for lowslope roots', Kunisch. Gimmi, Kunss, 45, (3), (1992), 195-202.

[4] Rossiter. W. J. Jr., 'Single-ply roofing - a decade of change". ASTM Sundardization Vius, Sep.. (1985), 32-34.

[5] Croce, S., 'Processual malysis of flat roofs pathology - Field experiences with pitched over-roofs', in J.O. May (Ed) Roots and Rooting, Ellis Horwood Ltd., Chichester, (1988), 123-137.

[6] Baxter, D.. 'Applicators must adjust to differences among modified bitumens', Professional Roofing, 21, (2), (1991), 52-60.

[7] Cullen. W. C., 'Project pinpoint's database continues to grow', Professional Roofing, 20. (4), (1990), 28-31.

[8] Höglund, I., Espling, R. and Hilding, G., 'Functional studies of flat roofs covered with membranes of butyl rubber', Building Research and Practice, 17. (5), (1989), 309-312.

[9] Ullman, H., 'Försäkringsbolagens säkerhetsföreskrifter för heta

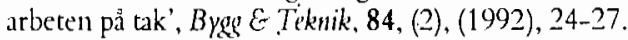

[10|Berglund, M., 'Skärpta säkerhetsbestämmelser betyder: Ingen tara pả taket', Bygg E Teknik, 83, (2), (1991), 39-40.

[1 1 Magnusson, S-E., 'Taken brinner alldeles för lätt', Brand $E$ Räddning, 6, (12), (1991), 26-29.

[12]Oba, K. and Björk, F.. Welding methods of single-ply polynermodified bituminous roofing naterials', Fire and Materials, 18, (1994), 351-358.

[13] Kinloch. A.J., 'Adhesion and adhesives', Chapman and Hall, London, (1987)

$[1+]$ Oba, K. and Björk. F.. 'The relationship becween welding temperature and $T$-peed strength of heat-welded seams in singleply roof coverings", I. Adhesion Si. Techol, 7, No. 9, (1993), 987-999.

[15]Watanabe, H. and Rositer. W. J., 'Effects of adhesive thickness, open time and surface cleanliness on the peel strength of adhesive-bonded seans of EPDM rubber membrane', in Roofing Research and Standards Development, Vol. 2, ASTM STP1088, (1990), 21-36.

[16]Hean. S.. Beständigkeit von Polynerbitumen-Dichtungsbahnen beim Gussasphalt-Einbau. EMPA-Nr. FE $137^{\prime} 08^{\circ}$. Swiss Federal Laboratories for Materials Testing and Research. Switzerland, (1992).

$[17 \mid$ Hendriks, N.A. and Woonink R. ,Field and laboratory investigations of the erazing phenomena of APP-modified bitumen sheetings: in Proceedings of VIIth International Roofing \& Waterproofing Congress. International Waterproofing Association. (1992), 177-195

[18]Baxter, R. and Kearnev. T., 'Weathering characteristics of polymer-modified asphalt rooting nembrane' in Proceedings of the 1991 Intemational Svmposium on Rooting Tethnology. National Roofing Contractors Association, Illinois, (1991), 453-458.

[19] Mathieu, L. and Pagnini. D.. Aging of polyalphaolefinic nodified biamen tor roofing membranes', ibid (1991), .459-466.

120|Diebold. T.. Polymer-modified binumen SBS vs. APP. Sopremia S.A., France (1988).

[21] Heinerikx. G.W J.. Snrenic block copolymers for bitumenbased roofing folt: Tailoring to application". in Proceedings of VIllch International Rooting \& Waterproofing Congress. International Waterprooting Association, (199?), 393-401.

[2-2]Oba, K. and Part. M. N.. Seam performance of polymer-modifed bicuminous rooting heers: EMPA-Forschung- und Arbeitsberiche No. 13616: FE 147'135. Swiss Federal Laboratories for Materials Testing and Research, Switzerland, (1994). 